\title{
THE ROLLER-GROUND DYNAMIC INTERACTION IN THE COMPACTION PROCESS THROUGH VIBRATIONS FOR ROAD CONSTRUCTION
}

Bejan Sergiu, dr.eng. Head of Chair of the Department DMMC, Technical University of Moldova;

\section{Rezumat}

Terenul natural utilizat în umplutură, în terasamentul căilor de comunicații, este caracterizat de următorii factori: umiditate, porozitate, compactitate. Pentru anumite valori ale factorilor ce descriu starea pământurilor, se remarcă o anumită comportare a terenului sub acţiunea forţelor exterioare aplicate prin mijloace mecanice static sau dinamic.

În această lucrare sunt prezentate rezultatele simulării numerice a interacțiunii compactor-teren pe baza modelului reologic complex și neliniar, propus de autor în rezultatul elaborării lucrării de cercetare, care ține seama de caracteristicile reale ale terenului (elastice, disipative și plastice) și de cele ale utilajului de compactat (cu un singur rulou vibrator). Modelul a fost armonizat și acordat în conformitate cu rezultatele obținute la prelucrarea datelor experimentale. Pentru simularea modelului a fost utilizat pachetul software specializat Matlab (Simulink, SimMechanics). Rezultatele obținute au evidențiat comportarea reală a utilajului și acțiunea sa asupra terenului supus compactării.

Cuvinte cheie: Terasamente, compactor, vibrații, umiditate, model reologic, dinamică.

\section{Abstract}

The natural soil used in filling the embankment of the road communications is characterized by the following factors: humidity, porosity, toughness. For certain factor values that describe the soil state is distinguished a certain soil behavior under the influence of the external forces applied through static or dynamic mechanical means.

In this study are presented the numeric simulation results of the soil-compactor interaction based on the complex and nonlinear rheological model proposed by the author in the result of the elaborated doctorate thesis, that follows the real soil characteristics (elastic, dissipative and plastic) on those of the compaction equipment (with a single vibrating roll). The model was harmonised and granted in accordance with the results obtained from the processing of the experimental data. For the simulation model was used the specialized software package Matlab (Simulink, SimMechanics). The obtained results revealed the real behavior of the equipment and its action on the compacted soil.

Keywords: embankment, compactor, vibrations, humidity, rheological model, dynamics. 
ROMANIAN JOURNAL

OF TRANSPORT INFRASTRUCTURE

Bejan Sergiu

Roll - ground dynamic interaction in the compaction process by vibration for road construction

\section{MODELING THE INTERACTION.}

Based on the experimental determinations, resulted the functional relations of dependence between the essential parameters that describe the compaction process of a ground when knowing the information about the compacting machinery (static or dynamic), the ground that needs compaction and the final compaction degree must be realised at the end of the technological process. This connection relations allow the following the tandem "action-effect of an action" during the technological process, respectively the prediction of the obtained effect in the conditions of a known action. By the effect of an action, we understand, in this research, both the effects of the actions suffered by the ground, and those produced on the technological compaction equipment.

The elaboration of a mathematical model that simulates the behavior of a real (physical) system can be obtained by following the steps given in Figure 1.

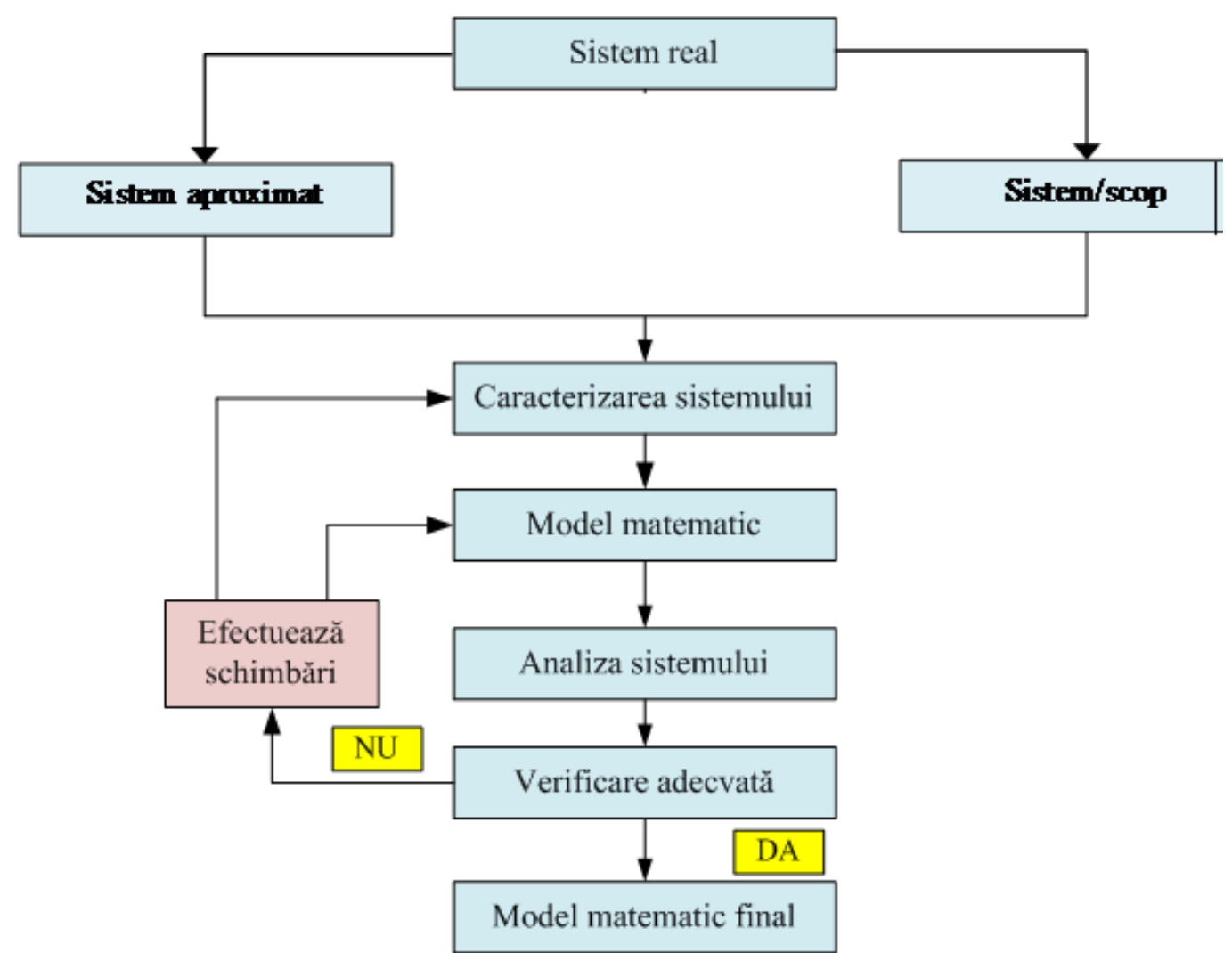

Figure 1. The steps of the elaboration of a mathematical model of the mechanical system [1] 
ROMANIAN JOURNAL

OF TRANSPORT INFRASTRUCTURE

Bejan Sergiu

Roll - ground dynamic interaction in the compaction process by vibration for road construction

\section{DYNAMIC MODEL FOR INTERACTION STUDY OF THE ROLLER- GROUND COMPACTION}

The simplest dynamic model for modelling the interaction between the roller and the ground, using a single vibrator roll, is presented in Figure 2. The model has a single liberty degree objectified in the displacement of the vibratory roll on a vertical direction $[2 ; 3]$.

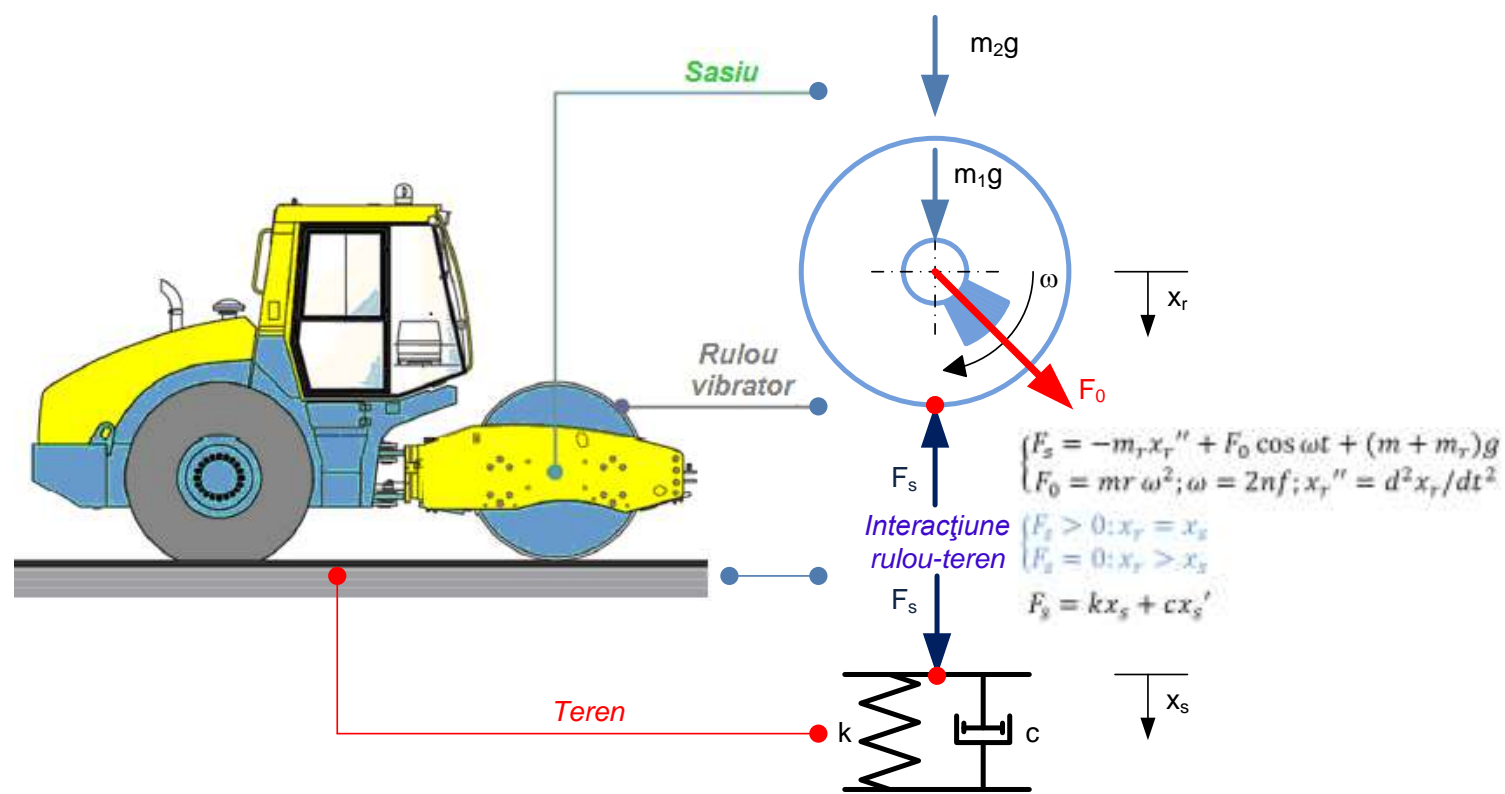

Figure. 2. The dynamic model with a single liberty degree for the interaction study roller-ground for a single vibrator roll.

The movement equation of the dynamic system presented in Figure 2 is:

$$
m_{r} \ddot{x}_{r}=\left(m+m_{r}\right) g+m_{0} r \omega^{2} \cos (\omega \cdot t)-F_{s}
$$

where: $m_{r}$ - is the mass of the vibrator roll; $m$ - the mass of the machinery chassis; $m_{0} r$ - the static moment of the eccentric pieces; $\omega$ - the pulsation of the disruptive force; $x_{r}$ - the vertical displacement of the chassis; $F_{s}$ - the contact force between the roller and the ground.

The force expression between the roller and the ground can also be written like:

$$
F_{s}=k x_{s}+c \dot{x}_{s}
$$

where $k$ represents the rigidity coefficient of the ground; $c$ - the coefficient of the ground amortization. The relation (2) is valid for $x_{s} \geq 0$, but for $x_{s}<0$ the force value $F_{s}$ is zero. 
ROMANIAN JOURNAL

OF TRANSPORT INFRASTRUCTURE

Bejan Sergiu

Roll - ground dynamic interaction in the compaction process by vibration for road construction

For the model movement analysis were considered the following identification data of the vibrator roll and ground: $m=1000 \mathrm{~kg} ; m_{r}=3000 \mathrm{~kg}$; $m_{0} r=5 . .20 \mathrm{kgm} ; \omega=0 . .5001 / 5 \mathrm{~Hz} ; k=(1 . .4) 10^{5} \mathrm{kN} / \mathrm{m} ; c=4.10 \mathrm{Ns} / \mathrm{m} ;$ in the figures 3.4...3.6

\subsection{The influence of the rigidity variation of the ground layer on the dynamic parameters}

The most eloquent behavior of the natural ground or of the ground stabilized with mineral products (lime, bitumen, concrete) or organic (enzymes, polienzymes) is described by two composed models: the Voght-Kelvin model and the Maxwell model.

In this research study will be elaborated models with a discreet variable rigidity. In this moment, for each pass of the vibrator roll on the same layer of ground will be realised a certain rigidity, so after $n$ passes will be reached $n$ values for the rigidities $\mathrm{k}_{1}, \mathrm{k}_{2} \ldots . . . \mathrm{k}_{\mathrm{n}}$.

The dynamic answer will be given through the following parameters: the amplitude of the immediate displacement of the vibrations, noted with $\mathrm{A}(\Omega, \zeta)$. This way for each model will be noticed the growing influence of the rigidity on the parametric values.

Finally, is presented the complete study for the same vibrator roll and the two rheological models.

\subsubsection{The Voigt - Kelvin (E/V) Model}

For the dynamic model are considered the following initial data:

$$
\begin{aligned}
& m=4000 \mathrm{Kg} ; \quad c=4 \cdot 10^{5} \mathrm{Ns} / \mathrm{m} ; \quad m_{0} r=20 \mathrm{Kg} \\
& \Omega=\omega \sqrt{\frac{m}{k}} k=(1,2,3,4) \cdot 10^{8} \mathrm{~N} / \mathrm{m} ; \quad \zeta=\zeta(k)=\frac{c}{2 \sqrt{\mathrm{km}}} ; \\
& \omega=0 \ldots . .500
\end{aligned}
$$

The amplitude has the form:

$$
A^{V-K}(\Omega, \zeta)=\frac{m_{0} r}{m} \cdot \frac{\Omega^{2}}{\sqrt{\left(1-\Omega^{2}\right)^{2}+4 \Omega^{2} \zeta^{2}}}
$$


ROMANIAN JOURNAL

\section{OF TRANSPORT INFRASTRUCTURE}

Bejan Sergiu

Roll - ground dynamic interaction in the compaction process by vibration for road construction

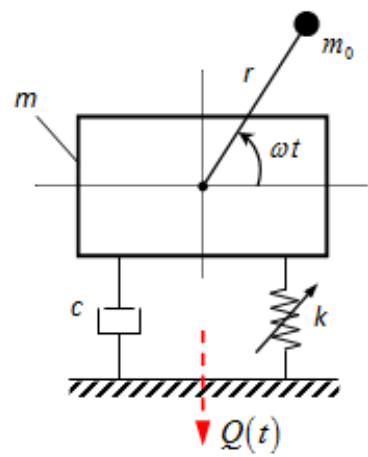

Figure. 3. The rheological Voight+Kelvin model.

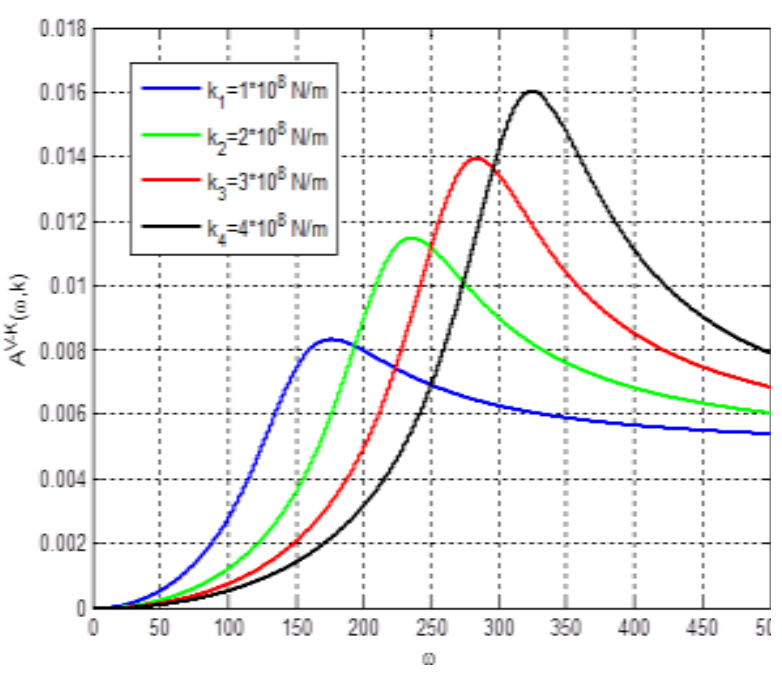

Figure. 4. The amplitude variation with the pulsation and rigidity.

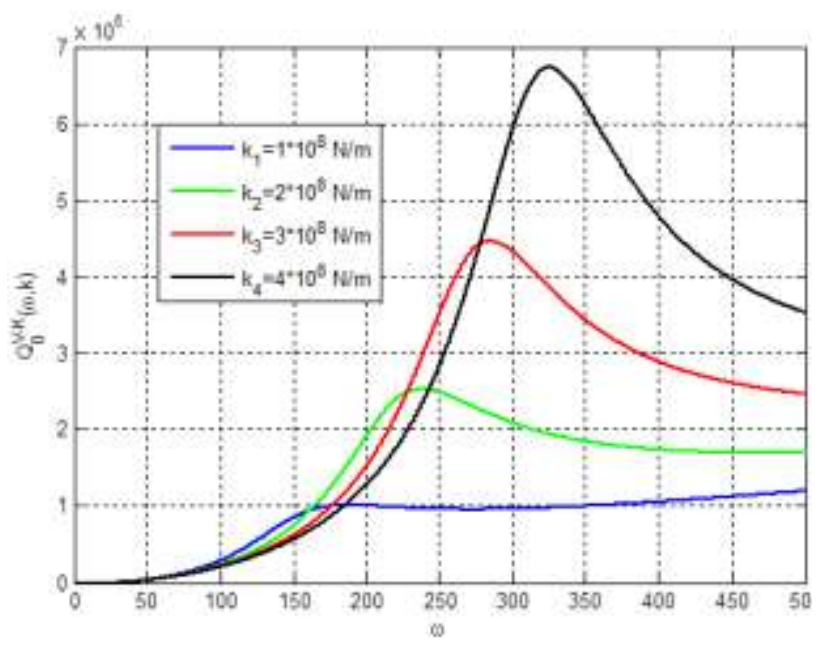

Figure. 5. The transmitted speed variation in relation with the pulsation.

The forwarded force in relation with the relative pulsation $\Omega=\frac{\omega}{p}=\omega \sqrt{\frac{m}{k}}$ and amortisation $\zeta$ is

$$
Q_{0}^{V-K}(\Omega, \zeta)=\frac{m_{0} r}{m} \cdot k \cdot \Omega^{2} \sqrt{\frac{1+4 \Omega^{2} \zeta^{2}}{\left(1-\Omega^{2}\right)^{2}+4 \Omega^{2} \zeta^{2}}}
$$


ROMANIAN JOURNAL

OF TRANSPORT INFRASTRUCTURE

Bejan Sergiu

Roll - ground dynamic interaction in the compaction process by vibration for road construction

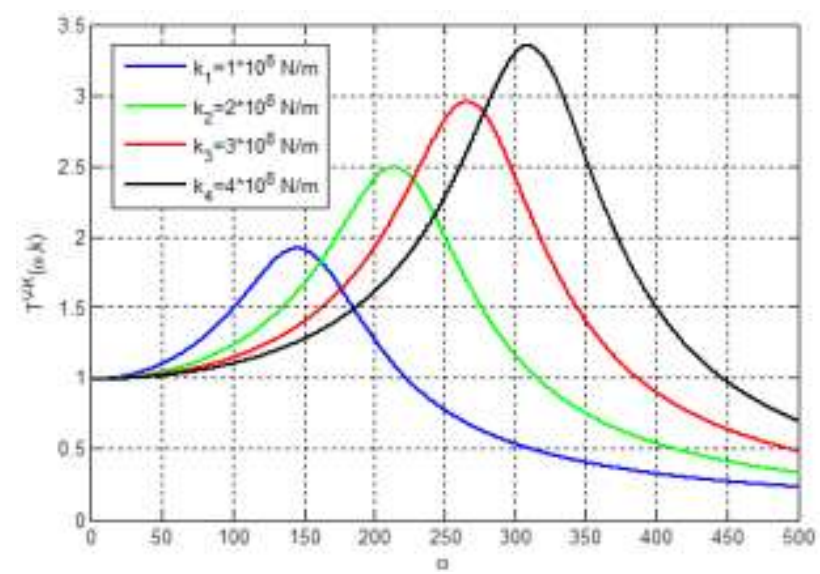

Figure. 6. The transmissibility variation in relation with the pulsation.

Is ascertained that the forwarded force depends on the static moment of the vibrator, the roller's mass, rigidity of the ground layer after compaction, the relative pulsation and amortisation from where is ascertained that the transmissibility depends only on the rigidity and amortisation of the ground.

De dynamic transmissibility is given by the formula:

$$
T^{V-K}(\Omega, \zeta)=\sqrt{\frac{1+4 \Omega^{2} \zeta^{2}}{\left(1-\Omega^{2}\right)^{2}+4 \Omega^{2} \zeta^{2}}}
$$

\subsubsection{The Maxwell (E - V) Model}

The rheological model given in Figure 7 is composed from two simple rheological elements, $\boldsymbol{k}$ and $\boldsymbol{c}$, in series. In this case, the variable rigidity attracts the modification of the relative pulsation and of the fractions for the critical amortisation.

The amplitude has the following form:

$$
A^{M}(\Omega, \zeta)=\frac{m_{0} r}{m} \Omega^{2} \sqrt{\frac{1+4 \Omega^{2} \zeta^{2}}{\Omega^{4}+4 \Omega^{2} \zeta^{2}\left(1-\Omega^{2}\right)^{2}}}
$$


ROMANIAN JOURNAL

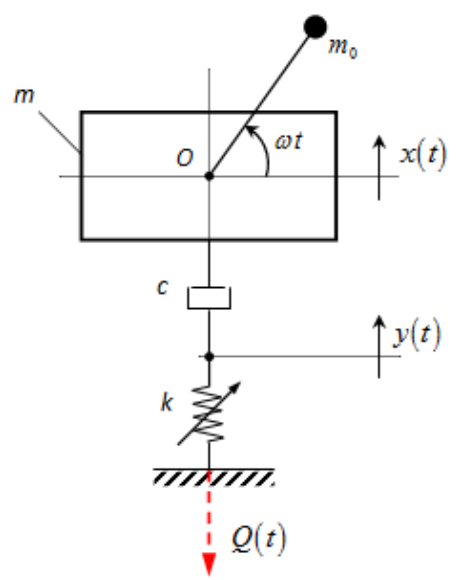

Figure. 7. The rheological Maxwel model.

The forwarded force to the ground is given by the relation:

$$
Q_{0}^{M}(\Omega, \zeta)=\frac{m_{0} r}{m} k \Omega^{2} \frac{2 \zeta}{\sqrt{\Omega^{2}+4 \zeta^{2}\left(1-\Omega^{2}\right)^{2}}}
$$

and directly depends by the relative pulsation and rigidity that leads to the curves represented in Figure 9, with the specification that the amortisation factor is determiner. So, if $\mathrm{c} \equiv 0$ and if $\zeta \equiv 0$, than the transmissibility is cancelled.

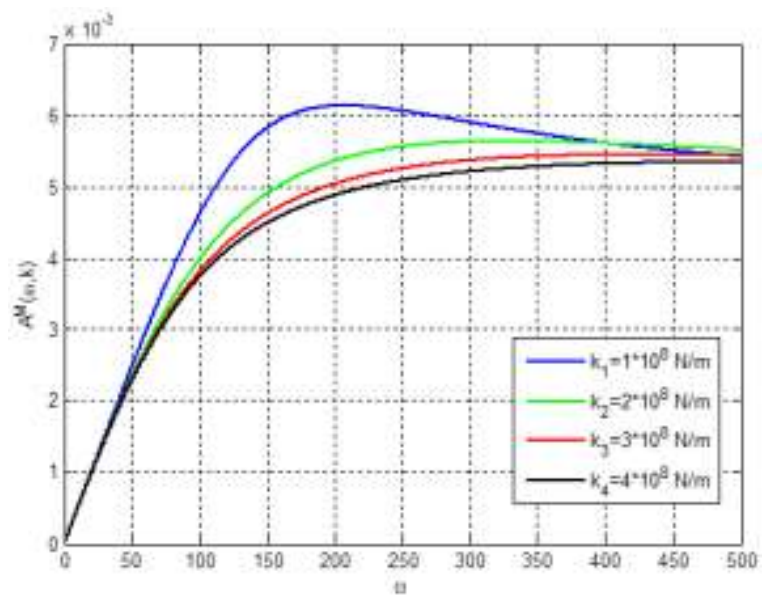

Figure. 8. The amplitude variation with the pulsation.

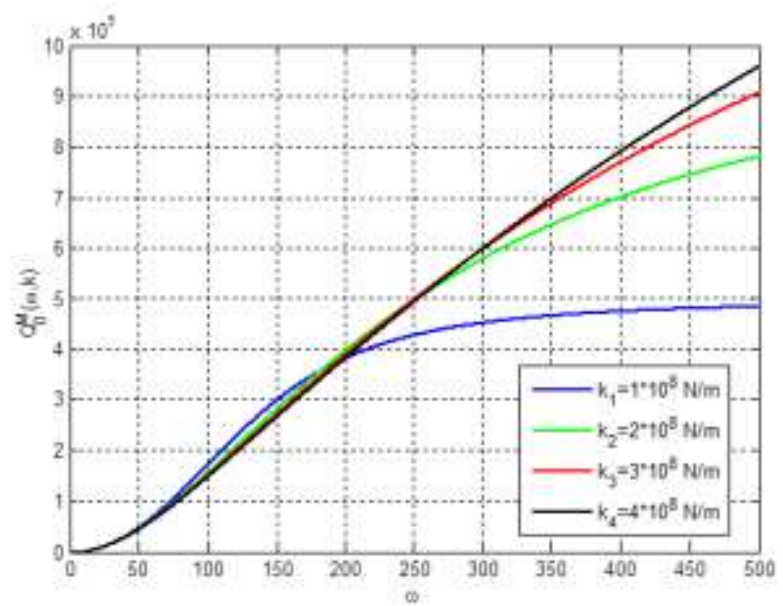

Figure. 9. The force variation with the pulsation.

The force transmissibility is given by the formula:

$$
T^{M}(\Omega, \zeta)=\frac{2 \zeta}{\sqrt{\Omega^{2}+4 \zeta^{2}\left(1-\Omega^{2}\right)^{2}}}
$$


ROMANIAN JOURNAL

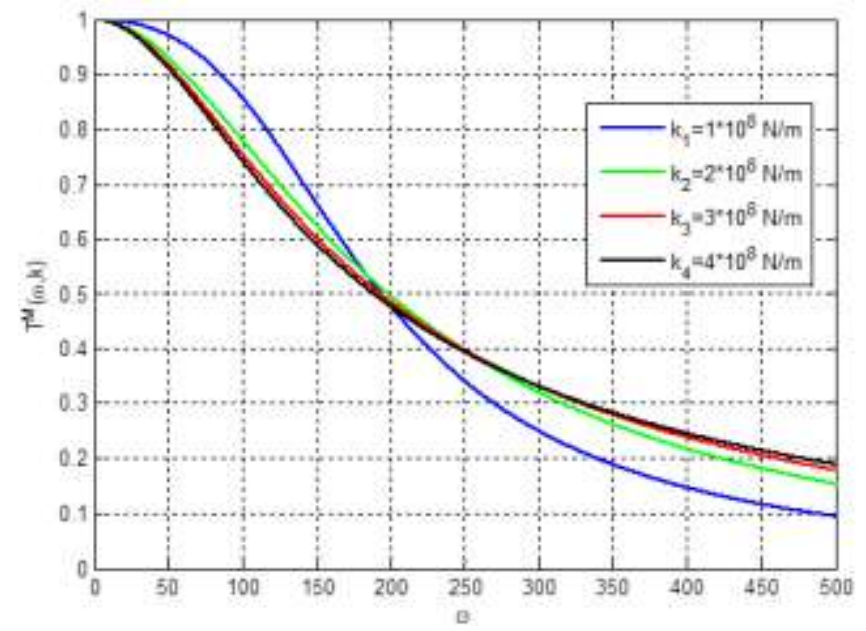

Figure. 10. The transmissibility variation with the pulsation.

Based on the diagrams from Figures 8, 9 and 10 is ascertained that the forwarded effect of the force is much reduced at high pulsations of the vibration.

For this reason, the poor cohesive, sandy grounds, with plenty of water in the structural content are difficult or almost impossible to compact.

For this are used chemical or organic stabilizers that can modify the rheological behavior.

In conclusion, is noticed that the Vogt-Kelvin model is the one that ensures a better transmissibility for the post resonance domain and leads to expected results of the compaction degree.

\section{CONCLUSIONS}

Models and systems of analysis can be realised informatively and numerical, with the coherent integration for the evolution of the essential parameters that characterize the technological process of dynamic compaction through vibration. Underlining the ground answer under the action of the dynamic force produced by the vibrator roll, together with its components in rheological terms of the composite materials with a complex elastic, dissipative and plastic type behavior, helps understand the specific phenomenology of the equipment-ground interaction and facilitates the technological optimization process through the improvement of the functional performances of the technological equipment specific for the dynamic compaction. The final purpose of this optimization is to obtain higher values of the compaction degree. 
ROMANIAN JOURNAL

OF TRANSPORT INFRASTRUCTURE

Bejan Sergiu

Roll - ground dynamic interaction in the compaction process by vibration for road construction

This way the analysis of the dynamic compaction process through vibration is necessary by using the combined methods for the technological equipment, with those advanced towards the ground rheology (with the optimization of the parameters specific for the typology of the working zone) and with elements specific for the way of working (implementation of the technological structure of approach of the dynamic compaction process). It results that it is required a pre-evaluation of the ground answer and of the request status imposed by the equipment, followed by the complex simulation of the cumulative effect produced by the successive passes and the in depth evaluation of the compaction degree on the entire zone of interest, with the real dynamic simulation of the dynamic actions and with the sweep on the entire monitorized zone.

\section{BIBLIOGRAPHY}

[1]. GANCIU T.: "Identificarea sistemelor”, Editura Nord-Est, Iași, Romania,1995;

[2]. THURNER, H.F., SANDSTRÖM, A.: „Continuous Compaction Control”, CCC, European Workshop Compaction of Soils and Granular Materials, Paris, May $19^{\text {th }}$, pp. 237-246, 2000;

[3]. WHITE, D., THOMPSON, M.: „Relationships Between In Situ and Roller-Integrated Compaction Measurements for Granular Soils", Journal of Geotechnical and Geoenvironmental Engineering, ASCE, Vol. 134, No. 12, pp. 1763-1770, 2008; 